\title{
Study on Palmar Dermatoglyphics and their Association with $\beta$ Thalassemia Major Patients among Bangladeshi Population
}

\author{
*A Zahan1, H Naushaba², UK Paul', AHMM Islam4, S Moin ${ }^{5}$, A Begum
}

\begin{abstract}
Objectives: To observe the palmar dermatoglyphic patterns of $\beta$-thalassemia major patients. Methods: This cross-sectional type of analytical study was performed in the Department of Anatomy, Sir Sallimullah Medical College, Dhaka between the periods of January 2016 to December 2016. $55 \beta$ thalassemia major patients aged between (5-35) years were considered as case group and 55 healthy individuals of the same age \& sex were considered as control group in this study. The palmar dermatoglyphic patterns and Total Finger Ridge count (TFRC) on the distal phalanges of the $\beta$ thalassemia major patients were observed and compared with healthy individuals. Results: The palmar dermatoglyphic patterns were significantly different between the two groups $(p>0.05)$. The mean $( \pm S D)$ of Total Finger Ridge count (TFRC) were higher in $\beta$ thalassemia major patients in comparison to the healthy individuals. Conclusion: This study concludes that, palmar dermatoglyphic has a diagnostic value for $\beta$ thalassemia major patients.
\end{abstract}

Keywords: Dermatoglyphic, $\beta$ thalassemia major, Total Finger Ridge count, Bangladeshi population.

\section{Introduction}

Dermatoglyphics (Greek Derma=skin, glyph=Carving) is the scientific study of the epidermal ridge patterns of the hairless surface of the skin. ${ }^{1}$ Dermatoglyphics are formed by the epidermis of skin during early intrauterine life between 14th to 21st weeks of gestation. ${ }^{2}$ Genetic and environmental factors like - UV-rays, X-rays, Rubella virus, etc. have an influence over alteration of normal dermatoglyphics. ${ }^{3,4}$ The term dermatoglyphic was first used by Dr. Harold Cumin in $1926 .^{5}$ The dermatoglyphic patterns of human palm and sole are individually unique. The fingerprints of identical twins may be similar in appearance but truly not identical. Dermatoglyphics pattern are not distorted in superficial injuries that produce scar in the

1. Dr. Afroj Zahan, Assistant Professor \& Head, Department of Anatomy, Gazi Medical college, Khulna.

Email: ana.santafroj1458@gmail.com

2. Professor Dr. Humaira Naushaba, Professor \& Head, Department of Anatomy, Dhaka Medical College, Dhaka.

3. Professor Dr. Uttam Kumar Paul, Professor \& Head, Department of Anatomy, Sir Salimullah Medical College, Dhaka.

4. Dr. AHM Mazharul Islam, Assistant Professor, Department of Anatomy,

Sheikh Hasina National Institute of Burn \& Plastic Surgery, Dhaka.

5. Dr. Sharna Moin, Assistant Professor, Department of Anatomy, Army Medical College, Jashore.

6. Dr. Arifa Begum, Assistant Professor, Department of Physiology, Gazi Medical College, Khulna. 
epidermis. Dermatoglyphics are distorted in severe injuries like-deep burn, electric injury which produce scar in the dermis. In 1892 Sir Francis Galton classified dermatoglyphics of human fingertips into loop $60-70 \%$, whorl $25-35 \%$ \& arch pattern $6-7 \% .^{6}$ The dermatoglyphic of palm contains a great deal of information which is of great research and clinical application value. ${ }^{7}$ Now, dermatoglyphics have been proven to be a helpful tool in identifying genetic diseases which have a strong hereditary basis such as thalassemia, Ca-cervix, Ca-breast, Ca-colon, retinoblastoma, psychological disorders e.g.-depression, schizophrenia, neurological disease such as epilepsy, skin diseases like psoriasis, leprosy, vitiligo, genetic disorders e.g.- Down's syndrome, Klinefelter syndrome and many other medical conditions e.g.- diabetes, hypertension, coronary artery disease, bronchial asthma, pulmonary tuberculosis. ${ }^{3}$ The thalassemia is a heterogeneous group of disorders caused by gene mutation. In thalassemia there is a genetically determined reduction in the rate of synthesis of one or more types of normal haemoglobin polypeptide chain. $^{8}$

Thalassemia is gradually increasing and becoming an important health burden in many parts of Asia. ${ }^{9} \beta$ thalassemia is most common among population of Mediterraneans $2-18 \%$, Africans $0-8 \%$ and South Asians 0-11\%. ${ }^{10}$ According to World Health Organization (WHO) approximately 6000 thalassemic children are born each year in Bangladesh. Among them $3 \%$ are carriers of $\beta$-thalassemia and $4 \%$ are carriers of $\mathrm{Hb}-\mathrm{E} \beta$ - thalassemia. $A$ recent study showed that carrier state of $\mathrm{Hb}-\mathrm{E}$ $\beta$-thalassemia is $6.1 \%$ and as high as $40 \%$ in tribal children in Bangladesh. ${ }^{11}$ Unusual dermatoglyphics are reported in patients with single gene disorders. Thalassemia is the most common clinically serious single gene disorder in the world. ${ }^{12}$

As thalassemia is a single gene disorder so it too can be added to this list. Dermatoglyphic patterns in male $\beta$ thalassemia major patients can be used as risk indicator. This may be used as a preliminary screening method to determine those at risk of developing $\beta$ thalassemia major and proper monitoring can be instituted to prevent morbidity and mortality associated with this condition. This study provides the relationship between the palmar dermatoglyphic patterns \& $\beta$ thalassemia major. $^{7}$

\section{Methodology}

This cross sectional type of analytical study study was carried out in the Department of Anatomy, Sir Salimullah Medical College, Dhaka, Bangladesh between the periods of January 2016 to December 2016. Ethical approval was taken from the Institutional Review Committee of Sir Salimullah Medical College, Dhaka. Fifty five $\beta$ thalassemia major patients aged between (5-35) years were considered as case group and fifty five healthy individuals of the same age \& sex were considered as control group for this study. All the subjects were free from other congenital or acquired deformities of finger and palm of hand.

Study subjects were selected from the transfusion medicine department (day care) of Bangabandhu Sheikh Mujib Medical University, Dhaka, on the basis of $\mathrm{Hb}$ electrophoresis. Fingerprints of case group were collected with due permission from the chairman of the department of Transfusion Medicine of Bangabandhu Sheikh Mujib Medical University, Dhaka. The healthy individuals were selected from students of class 1 to 5 of Chairkulpuddi Govt. primary school, Madaripur and MBBS \& BDS students of Sir Salimullah Medical College.

During the selection of study population, a data sheet of personal information was filled up for both groups to avoid duplication. Fingerprints of control group were collected with due permission from the headmaster of 
the Chairkulpuddi Govt. primary school, Madaripur and the principal of Sir Salimullah Medical College, Dhaka. Informed written consent was taken from both case and control group. Age of the subject was recorded from birth certificate or from national identity cards.

After selection of the subjects, dermatoglyphic print was taken by the ink \& paper method. Hands of each individual were washed with soap before inking to remove the dirt from hands. Then the hands were wiped with a dry towel. Two white papers were fixed on clip board to take the print of both hands. Both hands were painted with ink and both hand prints were taken. Both hands of the individuals were cleaned with turpin oil and soap and wiped with towel.

Then dermatoglyphics of each hand were studied with magnifying glass of $4 \mathrm{X}$ and $6 \mathrm{X}$ to identify the finger ridges for determination of different dermatoglyphic patterns \& TFRC. Sir Francis Galton, in 1892 classified the dermatoglyphics into three patterns - whorls, loops and arches. In Whorl pattern epidermal ridges form circle or spiral with a central core. In Ulnar or radial loop pattern epidermal ridges start on one side - either ulnar or radial side rise towards the center and return back to the side they started from.

In arches pattern epidermal ridges start on one side, rise towards the center and then leave on the other side. ${ }^{4}$ Total finger ridge count (TFRC) represents the sum of ridge counts of all ten digits. ${ }^{13}$ Total finger ridges were counted by taking the number of ridges from the tri-radius to the core pattern connected by a straight line of all the digit of both hands. The core forms the center of the pattern area.

Delta or tri-radius is located at the meeting point of three opposing ridge systems. A triangle is formed at the center. ${ }^{14}$ Data were expressed as mean $( \pm S D)$ and statistical significance of difference among the group was calculated by unpaired student's t-test.
Statistical analysis was done by using SPSS for windows version-21. P-value $<0.05$ was considered as significant.

\section{Results}

In the present study different finger ridge patterns (ulnar loop, whorl, arch and radial loop) in the distal phalanges of hands \& TFRC were studied. It was noticed that in male patients (case), percentage of radial loop were significantly higher in right hand $(P<0.000)$, radial loop $\left(p<0.000^{\star \star}\right)$ and whorl pattern $(\mathrm{P}<0.05)$ were significantly higher in left hand $\left(p<0.000^{\star *}\right)$, radial loop $\left(p<0.000^{* \star}\right)$ and whorl pattern $(P<0.05)$ were significantly higher in both hands.

It was also found that, percentage of arch pattern were significantly higher in right hand $(P<0.05)$, left hand $\left(p<0.005^{\star *}\right) \&$ both hands $\left(p<0.005^{\star *}\right)$ of female patients (case) than control. Mean total finger ridge count was higher in both male $(P<0.000)$ and female case $(P<0.05)$ groups than in male and female control groups. 
Table 01: Comparison of different dermatoglyphic patterns in distal phalanges of hands in case and control group

\begin{tabular}{|c|c|c|c|c|c|c|}
\hline \multirow{2}{*}{ Sex } & \multirow{2}{*}{$\begin{array}{c}\text { Hand in } \\
\text { different } \\
\text { groups }\end{array}$} & \multirow{2}{*}{$\begin{array}{c}\text { Different } \\
\text { groups }\end{array}$} & \multicolumn{4}{|c|}{ Pattern in distal phalanges (\%) } \\
\hline & & & UL & W & $A$ & $\mathrm{RL}$ \\
\hline \multirow[t]{3}{*}{ Male } & \multirow[t]{3}{*}{ Right hand } & Case $(n=30)$ & $87(58 \%)$ & $48(32 \%)$ & $6(4 \%)$ & $9(6 \%)$ \\
\hline & & Control $(n=24)$ & $70(58.3 \%)$ & $37(30.8 \%)$ & $12(10 \%)$ & $1(0.8 \%)$ \\
\hline & & $P$ value & $0.783^{\text {ns }}$ & $0.091^{\mathrm{ns}}$ & $0.023^{*}$ & $0.000^{* *}$ \\
\hline \multirow[t]{3}{*}{ Female } & \multirow[t]{3}{*}{ Right hand } & Case $(n=25)$ & $102(81.6 \%)$ & $12(9.6 \%)$ & $8(6.4 \%)$ & $3(2.4 \%)$ \\
\hline & & Control $(n=31)$ & $114(73.6 \%)$ & $34(21.9 \%)$ & $5(3.2 \%)$ & $2(1.3 \%)$ \\
\hline & & $P$ value & $0.031^{*}$ & $0.000^{* *}$ & $0.042^{*}$ & $0.217^{\mathrm{ns}}$ \\
\hline \multirow[t]{3}{*}{ Male } & \multirow[t]{3}{*}{ Left hand } & Case $(n=30)$ & $75(50 \%)$ & $58(38.7 \%)$ & $8(5.3 \%)$ & $9(6 \%)$ \\
\hline & & Control $(n=24)$ & $77(64.2 \%)$ & $34(28.3 \%)$ & $9(7.5 \%)$ & $0(0 \%)$ \\
\hline & & $P$ value & $0.014^{*}$ & $0.023^{*}$ & $0.075^{\mathrm{ns}}$ & $0.000^{* *}$ \\
\hline \multirow[t]{3}{*}{ Female } & \multirow[t]{3}{*}{ Left hand } & Case $(n=25)$ & $97(77.6 \%)$ & $13(10.4 \%)$ & $12(9.6 \%)$ & $3(2.4 \%)$ \\
\hline & & Control(n=31) & $111(71.6 \%)$ & $35(22.6 \%)$ & $6(3.9 \%)$ & $3(1.9 \%)$ \\
\hline & & $P$ value & $0.043^{*}$ & $0.011^{*}$ & $0.032^{*}$ & $0.691^{\mathrm{ns}}$ \\
\hline \multirow[t]{3}{*}{ Male } & \multirow[t]{3}{*}{ Both hands } & Case $(n=30)$ & $162(54 \%)$ & $106(35.3 \%)$ & $14(4.7 \%)$ & $18(6 \%)$ \\
\hline & & Control $(n=24)$ & $147(61.3 \%)$ & $71(29.5 \%)$ & $21(8.8 \%)$ & $1(0.4 \%)$ \\
\hline & & $P$ value & $0.0397^{*}$ & $0.017^{*}$ & $0.018^{*}$ & $0.000^{* *}$ \\
\hline \multirow[t]{3}{*}{ Female } & \multirow[t]{3}{*}{ Both hands } & Case $(n=25)$ & $199(79.6 \%)$ & $25(10 \%)$ & $20(8 \%)$ & $6(2.4 \%)$ \\
\hline & & Control(n=31) & $225(72.6 \%)$ & $69(22.3 \%)$ & $11(3.5 \%)$ & $5(1.6 \%)$ \\
\hline & & $P$ value & $0.046^{*}$ & $0.019^{*}$ & $0.027^{*}$ & $0.117^{\text {ns }}$ \\
\hline
\end{tabular}

Case: ( $\beta$ Thalassemia major patients)

Control: Healthy individuals

Figure in parentheses indicate range. Comparison between study groups done by unpaired Student's t test, ${ }^{* *}=$ significant at $P$ value $<0.01,{ }^{*}=$ significant at $P$ value $<0.05$, ns $=$ not significant.

Table 01 displays frequencies of fingerprint patterns of right, left and both hands in the case and control groups of both sexes. Unpaired student's t-test shows significant difference between patterns of the case and control groups of male right $\left(p=0.000^{\star *}\right)$, left $\left(p=0.000^{*}\right)$ \& both hands $\left(p=0.000^{*}\right)$ and also in female right $\left(p=0.000^{* *}\right)$, left $\left(p=0.011^{*}\right) \&$ both hands $\left(p=0.019^{\star}\right)$. 


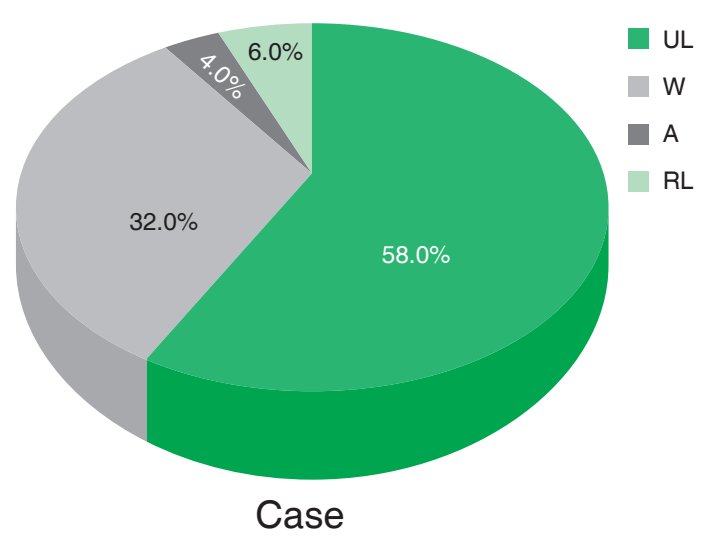

Right hand (Male)

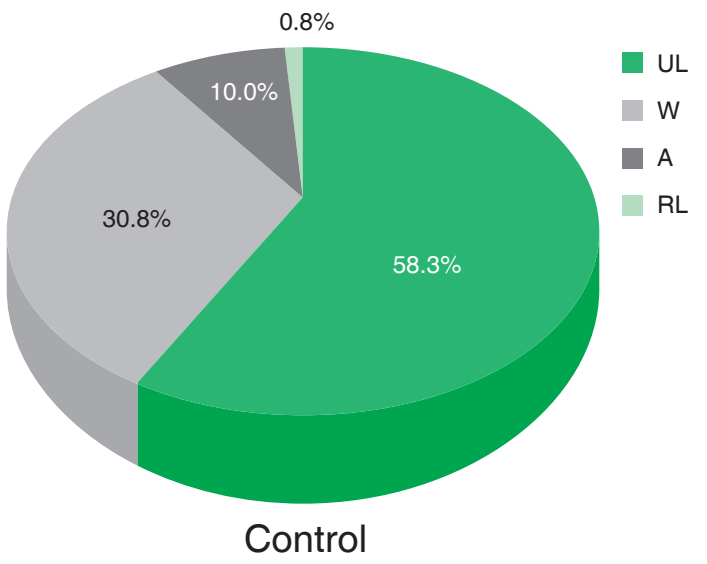

Figure 01.1a: Pie chart showing different dermatoglyphic patterns in distal phalanges of right hands of case ( $\beta$ Thalassemia major patients) and control (Healthy individuals) in male.

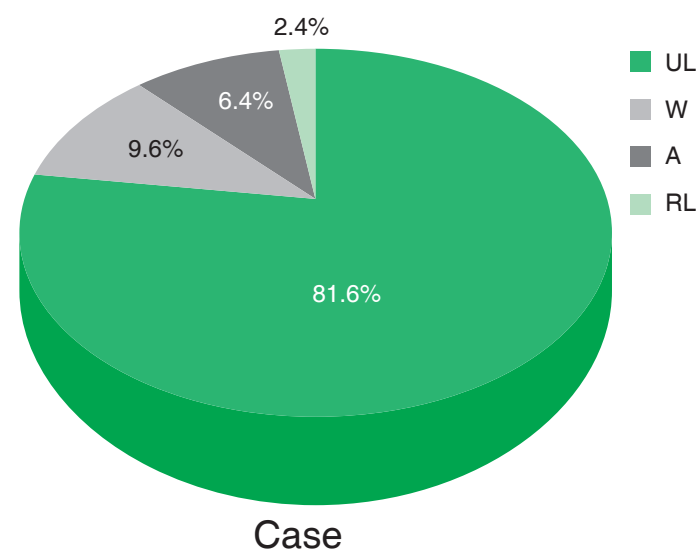

Right hand (Female)

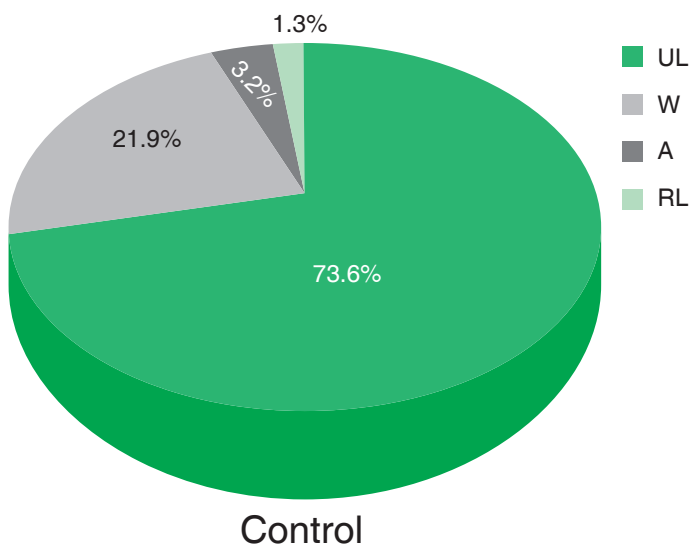

Figure 01.1b: Pie chart showing different dermatoglyphic patterns in distal phalanges of right hands of case ( $\beta$ Thalassemia major patients) and control (Healthy individuals) in female.

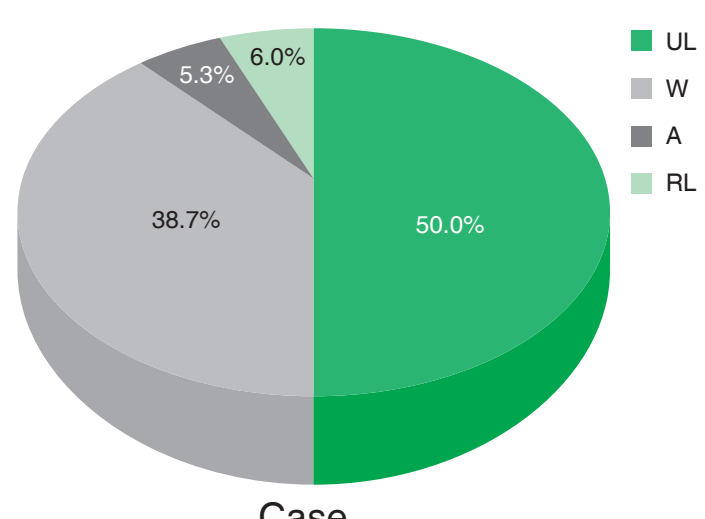

Case

Left hand (Male)

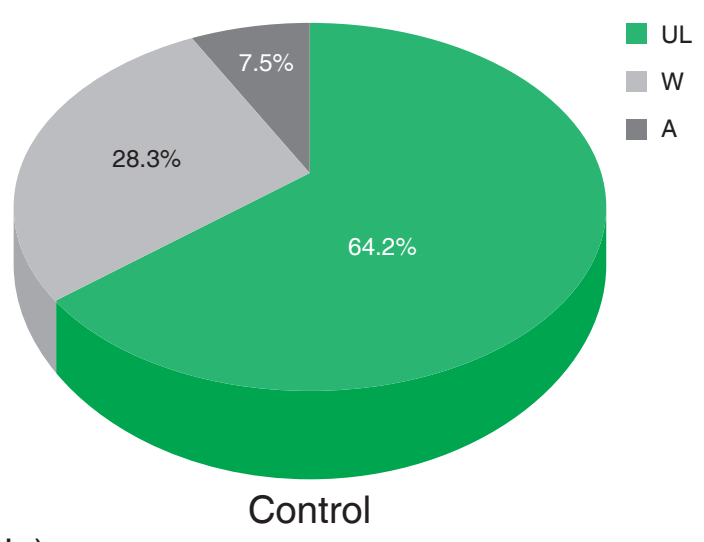

Figure 01.1c: Pie chart showing different dermatoglyphic patterns in distal phalanges of left hands of case ( $\beta$ Thalassemia major patients) and control (Healthy individuals) in male. 


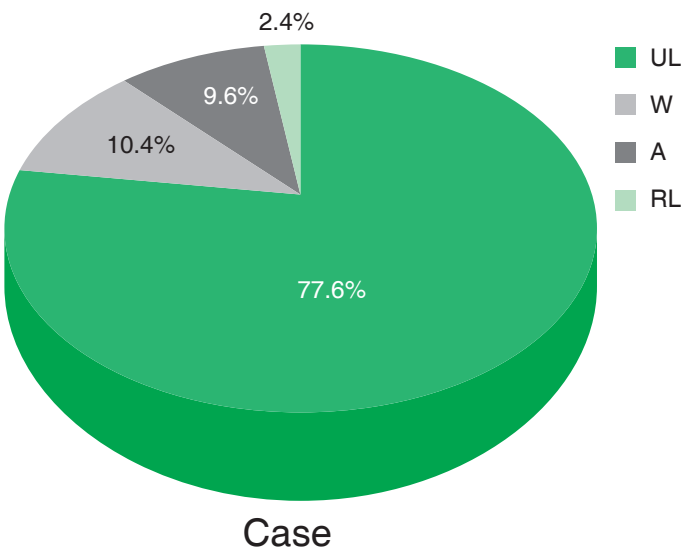

Left hand (Female)

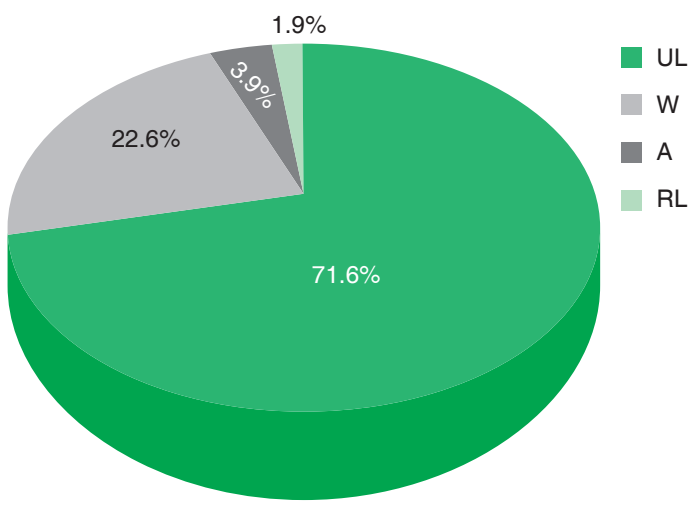

Control

Figure 01.1d: Pie chart showing different dermatoglyphic patterns in distal phalanges of left hands of case ( $\beta$ Thalassemia major patients) and control (Healthy individuals) in female.

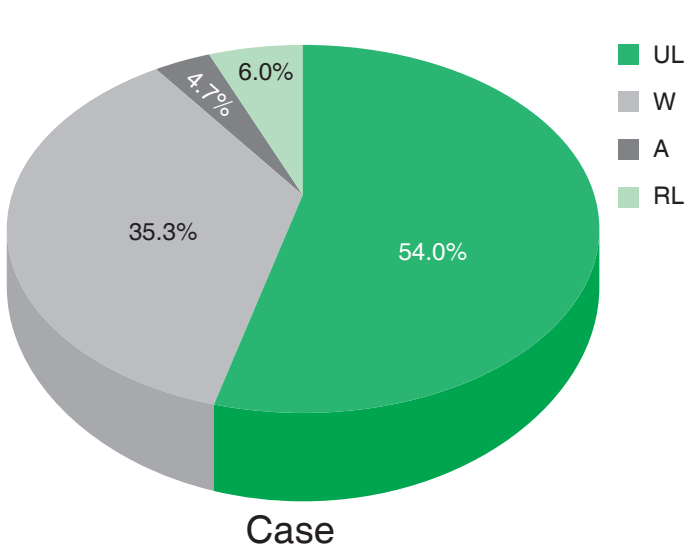

Both hands (Male)

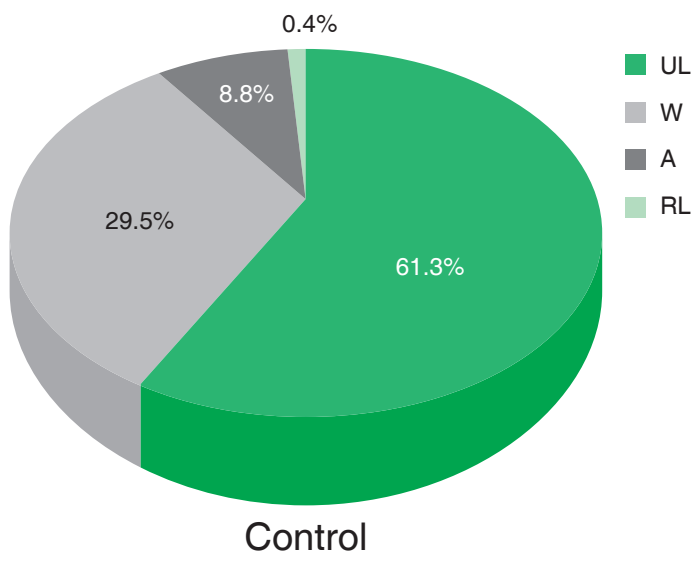

Figure 01.1e: Pie chart showing different dermatoglyphic patterns in distal phalanges of both hands of case ( $\beta$ Thalassemia major patients) and control (Healthy individuals) in male.
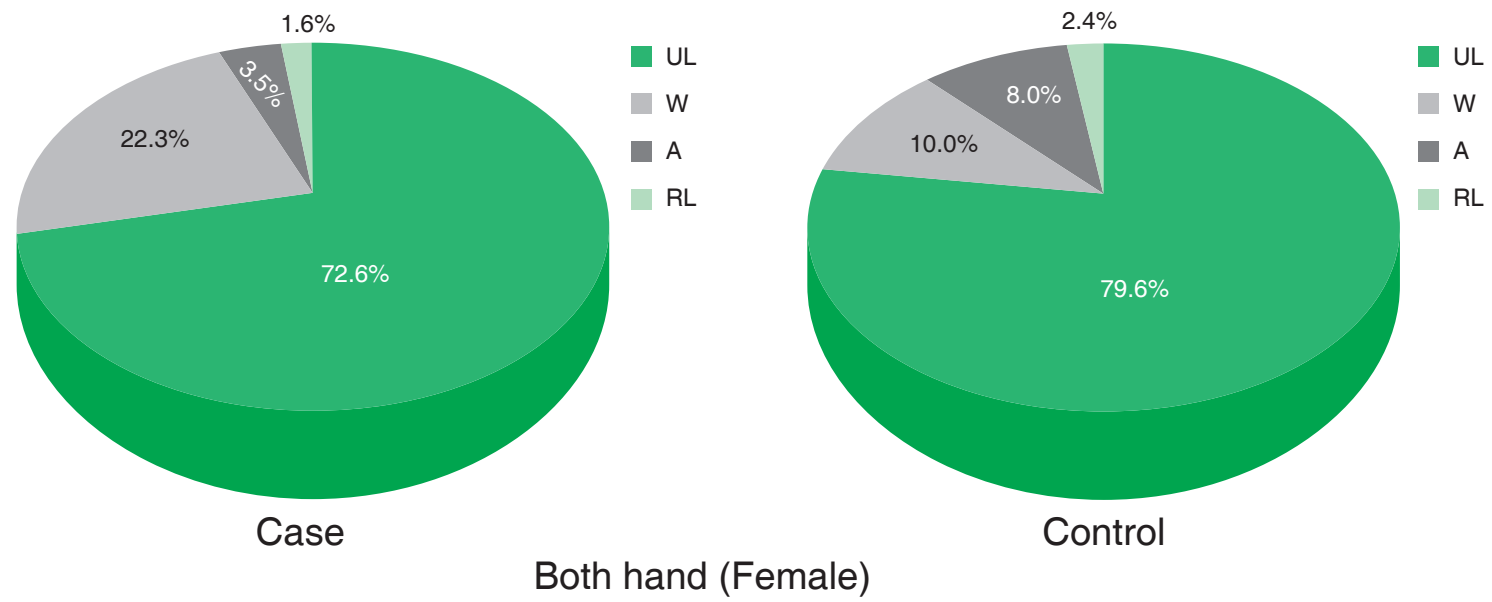

Figure 01.1f: Pie chart showing different dermatoglyphic patterns in distal phalanges of both hands of case ( $\beta$ Thalassemia major patients) and control (Healthy individuals) in female. 
Table 02: Total Finger Ridge Count of the study subjects

\begin{tabular}{|c|c|c|c|}
\hline Sex & Group & $\begin{array}{l}\text { Total finger ridge count } \\
\quad(\text { Mean } \pm \text { SD) }\end{array}$ & $\mathrm{P}$ value \\
\hline \multirow[b]{2}{*}{ Male } & $\begin{array}{l}\text { Case } \\
(n=30)\end{array}$ & $\begin{array}{c}105.70 \pm 30.18 \\
(28.0-165.0)\end{array}$ & \multirow[t]{2}{*}{$0.000^{* *}$} \\
\hline & $\begin{array}{l}\text { Control } \\
(n=24)\end{array}$ & $\begin{array}{l}68.04 \pm 28.27 \\
(16.0-128.0)\end{array}$ & \\
\hline \multirow[t]{2}{*}{ Female } & $\begin{array}{l}\text { Case } \\
(n=25)\end{array}$ & $\begin{array}{l}94.04 \pm 24.78 \\
(36.0-141.0)\end{array}$ & \multirow[t]{2}{*}{$0.047^{*}$} \\
\hline & $\begin{array}{l}\text { Control } \\
(n=31)\end{array}$ & $\begin{array}{l}80.03 \pm 32.72 \\
(34.0-145.0)\end{array}$ & \\
\hline
\end{tabular}

Figure in parentheses indicate range. Comparison between study group done by unpaired students "t" test, ${ }^{* *}=$ significant at $P$ value $<0.01,{ }^{*}=$ significant at $P$ value $<0.05$. Case: $\beta$ Thalassemia major patients, Control: Healthy individuals.

As shown in Table 02, the mean \pm SD of total finger ridge counts were $105.70 \pm 30.18$ and 68.04 \pm 28.27 for the male case and control groups respectively. Highly significant difference of total finger ridge counts were found when compared between two groups $(P<0.00)$. The mean $\pm S D$ of total finger ridge count in female case group was $94.04 \pm 24.78$ and in female control group was $80.03 \pm 32.72$. Significant difference of total finger ridge count was found when compared between two groups $(\mathrm{P}<0.05)$.

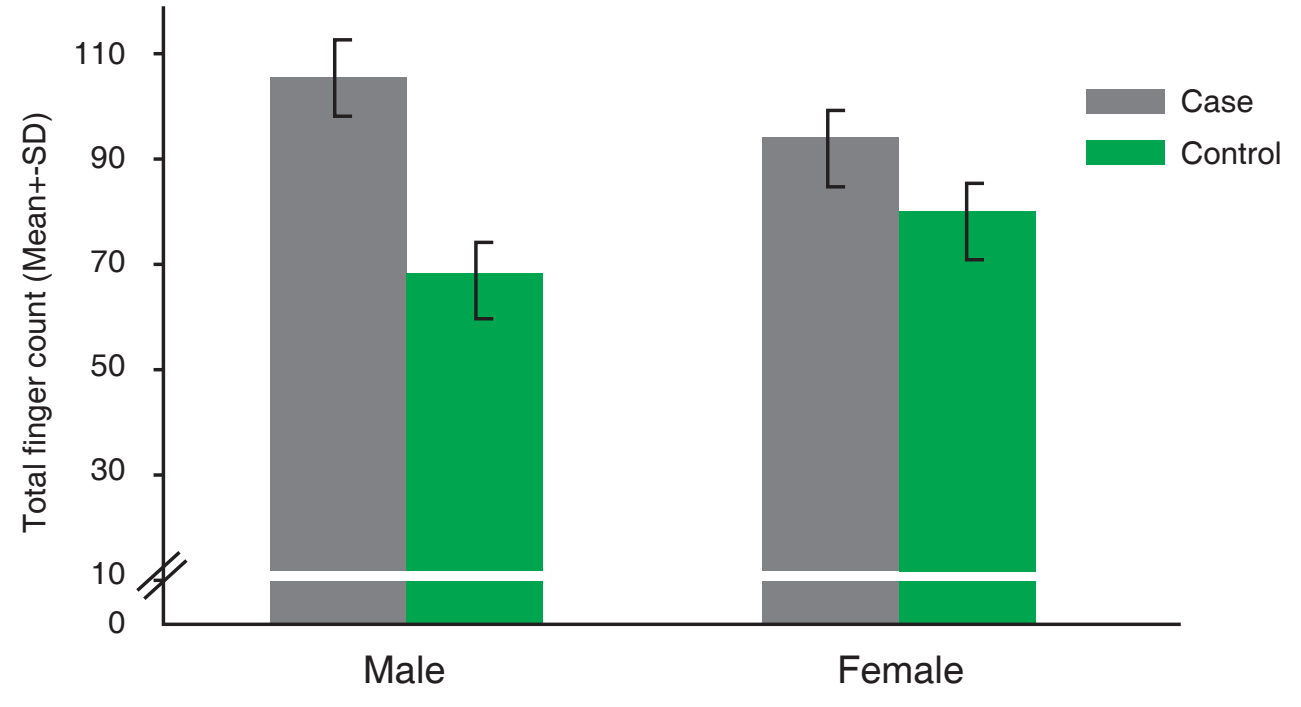

Case: $\beta$ Thalassemia major patients Control: Healthy individuals

Figure 02: Distribution of total finger ridge count of hands in case and control group.

\section{Discussion}

This study attempts to analyse whether any specific dermatoglyphics pattern exist for $\beta$ thalassemia major and whether that serves as an early diagnostic tool. We observed that dermatoglyphic patterns in the form of radial loop were more in distal phalanges of the 
digits in right hand, radial loop \& whorl in left hand and radial loop \& whorl in both hands of male case group when compared with control. Arch pattern were more in distal phalanges of the digits in right hand, left hand and both hands of female case group when compared with control groups. These observations coincides with the study of Das P., Ghosh J.R. and Bandyopadhyay A.R. ${ }^{15}$ they found increased number of whorl pattern in male and arch pattern in female $\beta$ thalassemia patients. This finding was similar with the present study. Saha K.C., Chatterjea J.B. and Mukherjee D.P. ${ }^{16}$ they observed increased number of whorl pattern in both male and female $\beta$ thalassemia major patients. This finding was similar with the present study in case of male patients but dissimilar in case of female $\beta$ thalassemia major patients. According to the study of Dogramaci A. C. ${ }^{17}$ frequency of whorl pattern was more in male and ulnar loop pattern was higher in female $\beta$ thalassemia major patients. This finding was similar with the present study in case of male patients and dissimilar in case of female patients. Solhi $\mathrm{H}$. et.al. $^{18}$ found that frequency of whorl pattern was more in both sex of $\beta$ thalassemia majorpatients which is similar with the present study in case of male patients and dissimilar in case of female patients. Basu D. et al. ${ }^{19}$ found higher percentage of whorl pattern in both sex of $\beta$ thalassemia major patient. This finding was similar with the present study in case of male patients but dissimilar in case of female patients.Our study shows that there is significant increase in TFRC in both male \& female $\beta$ thalassemic cases. These observations coincide with the study of Ganorkar Y. S. ${ }^{20}$ and Dogramaci A.C. ${ }^{17}$. They observed that total finger ridge count was significantly more in both male and female casethan control group. This finding was similar with the present study. Saha K.C., Chatterjea J.B. and Mukherjee D.P. ${ }^{16}$ reported that TFRC were higher in female $\beta$ thalassemia major patients than male patients. This finding was dissimilar with the present study. Stomeo C. and Tannonia $\mathrm{N}^{21}$ reported that TFRC was lower in both male and female study group. This result was dissimilar with the present study. Observed results of different variables showed some similarities as well as dissimilarities with the available information present on different publications. The similarities might be due to the fact that palmar dematoglyphics and $\beta$ thalassemia major both are genetically determined and once established, dermatoglyphic patterns remain unchanged throughout life. Dissimilarities might be due to racial factors which are also responsible for $\beta$ thalassemia major. During selection of study population some hereditary diseases like congenital heart disease, neurological disorder, psychological disorder, asthma, pulmonary tuberculosis etc. were excluded by history taking.

\section{Conclusion}

This study concludes that, we have observed specific dermatoglyphic patterns for the male $\&$ female $\beta$ thalassemia major patients of Bangladesh. Significant increase in number of total finger ridge count is also found in both sexes of $\beta$ thalassemia major patients. Our findings can be useful in the management of $\beta$ thalassemia major specifically at the level of prevention.

\section{References}

1. Rashida H.A., Dharati K., Nagar S.K. \&Bhaskar P., Palmar dermatoglyphics in patients of thalassemia major. National journal of medical research. 2012;2(3): 287-290.

2. Mulvihill J.J. \& Smith D.W., The genesis of dermatoglyphics. Journal of Pediatrics. 1969;75(4):579-89.

3. Kumbnani H.K., Dermatoglyphics : A Review, Anthropology Today : Trends Scope and Applications. Anthropologist Special. 2007b;3:285-95. 
4. Elsaadany H.M. et al., Can Dermatoglyphics be used as an Anatomical Marker in Egyptian Rheumatoid Patients? Journal of American Science. 2010;6(11):457-66.

5. Cummins H. \& Midlo, Palmar \& Plantar epidermal ridge configuration in European Americans. American journal of physical anthropology. 1926; 9:471-502.

6. Reddy K.S. \&Murty O.P.,The essentials of Forensic Medicine and Toxicology. ed33rd. New Delhi:Jaypee Brothers Medical Publishers (Pvt.) Ltd;1973.

7. Zhou Y., Zeng Y.Z., Lizhen\& Hu W., Application and development of palm print research. Technology and Health Care. 2002;10:383-390.

8. Kumar V., Abbas A.K. \& Aster J.C., Robbins \&CotranPathologic Basis of Disease. ed 9th. New Delhi:Reed Elsevier; 2014:638-644.

9. Reeds T., Reichmann A. \& Palmer C., Dermatoglyphic differences between 45 , $\mathrm{X}$ and other chromosomal abnormalities of Turner's syndrome. Human genetics. 1977;36:13-23.http://dx.doi.org/10.1007/ BF00390431.

10. Mohanty D., Colah R.B., Gorakshakar A.C., Patel R.Z., Master D.C., Mahanta J. et al., Prevalence of $\beta$ thalassemia and other haemoglobinopathies in six cities in India: A multicenter study. Journal of community genetics. 2013;4:33-34.

11. Khan W.A., Banu B., Amin S.K.. Prevalence of $b$ - Thalassemia Trait and $\mathrm{HbE}$ trait in bangladesh school children and health burden of thalassemia in our population. Dhaka Shishu (Child), Hosp J 2005;21:1-7.

12. Khan W.A. Thalassemia in Bangladesh. DS (Children) Hosp J. 1999;15:42-44.

13. Kar S. et al., Digito-palmar dermatoglyphics in vitiligo. Journal of the Saudi Society of Dermatology \& Dermatologic Surgery. 2012;16:61-6.
14. Gupta U.K. and Prakash S., Dermatoglyphics: a study of fingertip patterns in bronchial asthma and its genetic disposition. Kathmandu University Medical Journal. 2003;1(4): 267-271.

15. Das P., Ghosh J.R., \& Bandyopadhyay A.R., Association of Finger Ridge Pattern and EBeta-Thalassemia: A Study on Bengalee Population of West Bengal,India. Advances in Anthropology. 2015;5:19-21.http://dx.doi.org/10.4236/a a.2015.51002

16. Saha K.C., Chatterjea J.B., Mukherjee D.P., Dermatoglyphics in thalassaemia syndrome. J Indian Med Assoc. 1973;61:205-11.

17. Dogramaci A.C., Savas N., Bagriacik M.A.,Dermatoglyphs in patients with beta-thalassemia major and their thalassemia carrier parents. Collegium Antropologicum. 2009;33:607-11.

18. Solhi H., Hashemieh M., Nejad M.L., Vishteh H.R., Nejad M.R., Diagnostic value of fingerprint patterns: an explorative study on beta-thalassemia diagnosis. Bangladesh Medical Research Council Bulletin. 2010;36 (1) :27-31.

19. Basu P. et al.,Evaluation of the National Cervical Cancer Screening Programme of Bangladesh and the formulation of quality assurance guidelines. $J$ FamPlannReprod Health Care. 2014;36(3):131-34.

20. Ganorkar Y.S., Kwale S., Pandit S.V. and Jha R., Study of Dermatoglyphics in Thalassemia Major in Vidharbha Region by Quantitive Analysis of Finger Print. Journal of Dental and Medical Science. 2016;15(8):79-84.

21. Stomeo C., Tannoia N., Hand dermatoglyphics in a group of patients with thalassemia from Puglia. Minerva Pediatr. 1979; 31: 1085-90. 